\title{
Section:
}

\section{WORD AND TIME}

\section{IDIOSTYLISTIC PARAMETERS OF FICTIONAL DISCOURSE}

\author{
VITALIY KONONENKO
}

\begin{abstract}
The article discusses issues associated with identifying the authorial style of modern Ukrainian writers with an emphasis on trends in the development of a renewed writing manner. The author analyzes changes in fictional discourse in general and in the idiostyle of particular authors, which allows for the possibility of identifying patterns in the modernization of stylistic devices, the renewal of imagery, the development of novostyl*.
\end{abstract}

Keywords: authorial style, fictional discourse, idiolect, idiostyle, image, metaphor, movostyl*, novostyl, text.

\section{INTRODUCTION}

The authorial style of fiction writing is complicated to study due to a number of linguistic factors: there is no delimited set of necessary and sufficient expressive markers for identifying the characteristics of an author's writing style; there is a need to generate a set of stylistic features which will distinguish the texts of one author from those of other authors; it is necessary to develop a theoretical and methodological framework for describing the uniqueness of an author's movostyl within a literary trend; there is a need to provide principles for a comprehensive approach to systematizing the features of authorial diction. In this respect, quite symptomatic is the experience gained by the 20thcentury Ukrainian linguists who wrote a series of fundamental papers about the language of literary classics and their famous contemporaries [1; 11]; these studies give a rather comprehensive description of the lexical, morphological, and syntactic phenomena, as well as expressive devices found in the language of the writers who adhered to the artistic frameworks of their time, reflecting generally accepted literary norms.

Over the last few decades, linguists have explored a range of issues related to the stylistic diversity of fictional discourse primarily on the basis of a corpus of Ukrainian classical works of literature; there have emerged studies on the movostyl of those authors whose works either did not use to be a focus of research or were presented from a vulgar sociological perspective; yet, no consideration has been given to the numerous aspects of individualization, or specification, in the language and style of writers. Recent studies on the stylistic features of modern authors marked by an original writing manner have opened a novel perspective on the linguistic and literary movement (see, for instance, S. Ya. Yermolenko's article about the individual style of Ye. Pashynskyi, a representative of novostyl [5, p. 209-222]).

\footnotetext{
* Transl. note: novostyl is a transliteration of the Ukrainian term Hoвостиль, which means a new style.

* Transl. note: movostyl is a transliteration of the Ukrainian term мовостиль, which means language style.
} 
There is growing interest in how an individual style reflects the psychological basis of national identity, how an author's self-expression reflects the characteristics of a national mindset. A writer's associations and judgments, provided they are self-sufficient and unique, reflect, in one way or another, the language-mediated aspects of viewing a fictional world. From a topical perspective, authorial style must be examined within the context of modern objectives of a fictional narrative, which have arisen from the need to make a stronger impact on the reader's conscience, to establish priorities for a national language in literary art, and to introduce new literary norms. This article is intended to illustrate the novelty of modern Ukrainian narrative and to affirm the emergence of novostyl in language-mediated thought.

As O. V. Kulbabska notes, "increased interest in the individual features of writers' diction, in the reflection of the category of authorial individuality in a text has resulted in research on authorial style being regarded as a new branch of linguistics - idiostylistics, whose research findings identify the role of a writer in shaping the norms of a literary language, developing it and defining certain periods of its existence" [11, p.9]. An idiostyle expresses individual features found in an author's narrative art, i.e. his or her stylistic specification, whereas an idiolect characterizes the typical features of movostyl, which coordinates with linguistic personality, linguistic worldview, and linguistic type.

Modern Ukrainian fictional narrative writers have been making an increased effort to create a novel writing system; they have at least partially abandoned traditional textual forms, adopted modern expressive devices, involved novel word-formations, extended the scope of a literary norm, explicated living colloquial language. The change from the classical literary paradigm to novostyl has made way for modernist, postmodernist, naturalist, and other trends in the literary movement; elevated narrative art to the level of renewed language-mediated thought; caused a shift in the addresser-text-addressee relations, thus leading to readership division. The renewal of literary movostyl has also prompted a new perspective on characterizing original authorial writing, subjectivizing narrative manner, and opening prospects for objectivizing novostyl.

Owing to the changed perspectives on the movostyl of modern writers, it is necessary to provide a more accurate interpretation of an individual style, which is commonly defined only as "a set of linguistic expressive means which have an aesthetic function and distinguish the language of a particular writer among others" [6, p. 304]; in fact, in order to identify a particular author's style one must consider what defines their role in reflecting cultural, cognitive, psychological, and social aspects of discourse; their contribution to shaping a linguistic worldview, a culture-specific language style. Authorial style is a complex construct in a multi-dimensional linguistic framework.

\section{ANALYSIS AND DisCUSSION}

In order to identify an author's individual style, it is necessary to explore not only the linguistic aesthetics indicative of the fictional discourse of his or her epoch but also the original, novel markers with which the author has enriched the art of fiction writing. Authorial diction has traditionally been studied through fiction texts written exclusively by "great masters of literature" despite the fact that there is no conclusive approach to differentiating between "a famous master" and "a non-master"; moreover, and it is hardly necessary to provide such a differentiation considering that there are numerous instances of "little-known" authors writing outstanding pieces of literature. For instance, literary works of young writers can sometimes show new trends in the development of movostyl more prominently than the texts of renowned "traditionalists". Though the discourses of postmodernist authors may vary in terms of literary significance, they show distinct features of novostyl, which are worthy of being explored and interpreted as indicators of a renewed writing manner.

The issues associated with an individual style lie within the scope of the writer-reader relationship; the addressee normally has a passive role in text formation - he or she is supposed to grasp the meaning of texts, comment on them, explicate implicit (omitted) information and so on; the practice of communicating with a particular reader (but not with the readership as a whole) in such a way creates an intimate, subjective tone indicative of a "modernized" style. In an effort to come closer to the reader, 
the author may establish themselves as the I-narrator; this boosts the reader's trust in such communication; the author's intentions are reflected in his or her diction while being influenced by an "invisible" recipient.

Intersubjective relationships between the author and the reader, who are dependent on each other, are reflected in representing information implicitly or omitting parts of utterances with a view to urging the addressee to guess; such a text often contains a coded message left for the reader to decode. A particular style is created through combining two narrative planes (explicit and implicit) and realizing both the author's and the reader's intentions. Examples of hidden meaning are contained, for instance, in Ukrainian free verse, which sometimes takes a great deal of effort to interpret [see: 10]. Let us compare:
У квітні
(In April)*
по білому небу вишневого молока
(in a white sky of cherry red milk)
лimaюmь золоті птиці.
(golden birds are flying).
Золоті птиці дахів.
(Golden birds of roofs).
Вони політають-політають
(They will do some flying)
i, як голуби, знову сідають на хати.

(And, like doves, sit down on the cottages again) (V. Holoborodko).

Golden birds flying in a white sky in April are supposed to evoke elation, love, joy. Considering that "poetic meanings, like meanings in general, are situational and personality-specific" [7, p. 182], we must interpret obscure metaphors as hidden conceptualization.

Attempts to obscure the meaning of an utterance through understating or hiding its "internal form" often seem artificial, like a play on words; the stylistic homogeneity of such techniques reduces their attractiveness; the following postmodernist text is marked by increased intensity of paralinguistic cues intended to evoke an emotional response in the reader:"???????????" - запитав Перфецький. "..." була вidnoвidz (Yu. Andrukhovych. Perverziia) ("?????????????" asked Perfetskyi. "..." was the answer) (Yu. Andrukhovych. Perversion). By contrast, some of the author's other discourses have a different stylistic effect; for instance, a fiction text can be a mere description such as a sketch which does not separate the author's speech from that of the characters and is marked by a limited use of figurative devices, cf.: Суд, крім того, відмовився враховувати свідчення підсудного про "мольфарське закляття", але дійшов висновку про доціільність психіатричної експертизи. Модеrnité, яку так обожнював Маріо Поньраи, обернулася своїм зворотним боком - усезнайським апломбом $і$ скепсисом (Yu. Andrukhovych. Kokhantsi yustytsii) (The court, among other things, refused to consider the testimony of the accused about "a molfar's" spell" but reached the conclusion about the viability of a psychiatric expertise. Modernité, which Mario Pongrats adored so much, showed its reverse side - omniscient aplomb and skepticism (Yu. Andrukhovych. Lovers of Justice). The above-given extract contains many bookish words and phrases - враховувати свідчення (to consider the testimony), дійшов висновку (reached the conclusion), психіатричної експертизи (рsychiatric ехреrtise), апломбом і скепсисом (aplomb and skepticism) as well as the Latin borrowing modernité; the reference to a molfar's spell reflects the Galician origin of the text.

The author's ambivalent relationships with the reader are reflected in the tone of the narrative through a variety of devices such as implicature, ironic mockery, reduced pathetic appeal; such a manner presents a challenge to traditional figurative language. Such exertions can sometimes produce

\footnotetext{
* The paper is intended to illustrate the specifics of the Ukrainian language. Henceforth the translations preserve the content of the original, but not its morphological, semantic, syntactic, or stylistic properties.

* Transl. note: In Hutsul culture, a molfar is a practitioner of folk magic.
} 
a sarcastic effect, for instance when giving a critical evaluation of the political elite and common ideological notions:
Опротивіло буть українцем
(I'm sick and tired of being a Ukrainian)
Запишусь в хохли
(I'll get registered as a khokhol ${ }^{*}$ )
Є така дивовижна націл
(There's such a wonderful nation out there)
Я лисий вона вся чубата
(I'm bald they all have forelocks)
Запишусь матиму чуба.
(I'll get registered, grow a forelock) (I. Drach).

While reading between these sarcastic lines, one can trace a suggestion of anxiety, alarm: what does the future hold for our opposition to anti-Ukrainian attitudes?

In an effort to provide a contrast to grandiloquent writing style, modern authors draw on techniques of linguistic poetics such as parody, allusion, antinomy, and so on; noteworthy is the authorial approach to ironization. To illustrate, O. Zabuzhko's prose contains numerous instances of firm condemnation of certain attitudes; the author explores publicistic style. Compare: I не був mo адміністративний раж* (як кому сторонньому, ще й не надто тямкому, могло б видатися), ані, тим менше, намагання спасти власну шкуру (як випадало б висловитися, коли б не про дітей мова), а тільки яра, всепереможна хіть, хай і востанне, а таки мати Аенцю - наверненою й розкаяною, ревно благаючою прощення за зраду (O. Zabuzhko. Divchata) (And it was not administrative zeal (as it might have appeared to an outsider, not a particularly smart one at that), and even less likely was it a desire to save her hide (as it would have been appropriate to describe had it not been about the children), but rather an ardent, overpowering drive to have, even though it might be the last time, Lentsia come back all the same - remorseful, begging forgiveness for betrayal) (O. Zabuzhko. Girls). On the one hand, the above-given excerpt contains a number of publicistic phrases such as адміністративний раж (administrative zeal), всепереможна хіть (overpowering drive), благаючою прощення (begging forgiveness); on the other hand, there are colloquial phrases such as не надто тямкому (not particularly smart), намагання спасти власну икуру (а desire to save her hide); the syntax is extended with comment clauses, which transfers the narrative to the rank of a magazine article.

A manner of style has lately been viewed through the prism of "male-female" texts, which entails the existence of linguistic and aesthetic standards indicative of a Man's and a Woman's intonations, including those in a man's narrative about a woman and vice versa; there is a general tendency towards recognizing "the absurdity of regarding 'the male' and 'the female' as identical" [2, p. 220] at the level of discourse. A study of a "male" and a "female" writing manner is associated with numerous theoretical reservations. Firstly, there arises a problem of identifying "a male style" and "a female style": their characteristics, differences, and indicators at various levels of language structure, as well as the proportional representation of figures of speech, expressives; secondly, a male or female style manifests itself in first-person narratives more prominently than in texts where the narrator is detached from the story; thirdly, in some communicative situations a female author may be disguised as a man or vice versa. If, for example, women's intimate prose is focused on expressing typical female emotions and preoccupations, then such a tone may serve as a starting point for characterizing the "femaleness" of the narrative. In narratives by women writers, there can be references to the weakness of femininity, though they often carry ironic connotations; let us compare the expression of intimate feelings in the following example:

\footnotetext{
* Transl. note: The word khokhol refers to a long lock of hair left hanging from the top a shaven head, which was a common haircut of Ukrainian Cossacks; Ukrainians used the term among themselves as a form of ethnic identification; it is also used as a derogatory name for Ukrainians.

${ }^{*}$ Emphasis added here and in all subsequent examples.
} 
Моя любове! Я перед тобою.

(My love! I am in front of you.)

Бери мене в свої блаженні сни.

(Take me along to your blissful dreams) (L. Kostenko).

The desire to be with the loved one even in his dreams is a female characteristic. Gender-based issues are beginning to be viewed from an ironic perspective: Ілюзорна мить задоволення! Я готова обійняти всіх изих жінок. Обійняти й заплакати. І померти. Аби в понеділок була поважна причина не вийти на роботу (I. Rozdobudko. Odnoho razu...) (An illusionary moment of satisfaction! I am willing to hug all these women. Hug them and start crying. And die. So on Monday there will be a good excuse not to go to work) (I. Rozdobudko. Once upon a time...).

However, in V. Shkliar's narrative discourse, which is centered around depicting strong male characters, there are descriptions of bloody fights, with elements of a "male style" featuring rather prominently: У Иебединському лісі я звернувся до хлопців так, ніби нас був циілий загін. Не люблю красномовства, але ці слова йшли від серия. Я сказав, щзо нас залишилося троє, однак трійка - це організація. Бойова ланка партизанів. Тож продовжимо боротьбу за Украйну, за ї волю, за честь нашої зброї (V. Shkliar. Chornyi voron. Zalyshenets) (In Lebedyn forest, I addressed the guys as if there was a whole detachment of us there. I don't like eloquence, but these words were coming from the heart. I said that there were three of us left; however, three is an organization. A fire team of guerillas. So let's continue fighting for Ukraine, for its freedom, for the honor of our weapons) (V. Shkliar. A Black Raven. An Outcast). "Male" narrative style is reflected in mentions of загін (detachment), бойова ланка партизанів (a fire team of guerillas), боротьба за Україну (fighting for Ukraine), за честь нашої зброї (for the honor of our weapons), не люблю красномовства (I don't like eloquence).

The current development of style in its linguistic dimension is marked by significant changes in using textual metaphors. The traditional stereotypes of building metaphors and similes such as струнка як тополя (as slim as a poplar), дивитися як у воду (have second sight), губи як яzidки (lips like berries) and so on are becoming a thing of the past; let us compare them with novel metaphoric mappings:

Зоря над містом піднімае весла

(The morning star above the city is tossing the oars) (M. Vinhranovskyi).

Нехай тендітні пальцุі етики

(May the tender fingers of ethics)

Торкнуть вам серие $і$ вуста

(Touch your heart and lips) (L. Kostenko).

У білій стужі білих голосінь

(In the hard white frost of white laments)

цุі грона болю, щцо падуть в глибінь,

(these bunches of pain reaching deep down)

безсмертною бідою окошились

(brought forth immortal trouble) (V. Stus).

Let us consider the combinations of semantically distant words such as зоря niднімиа весла (the morning star is tossing the oars), nальиі етики торкнуть серие $i$ вуста (the fingers of ethics touch your heart and lips), стужа білих голосінь (the hard frost of white laments), грона болю падуть в глибінь (bипсhеs of pain reaching dеер dоwn), безсмертною бідою окоиихись (brought forth immortal trouble). Allusions come to be explicated in unusual figures of speech; to illustrate, let us consider S. Zhadan's image of Voroshylovhrad as an embodiment of former sovietdom: Ворошилов міг бути на коні, а міг бути й без коня. Що знову ж таки гірше, оскільки про коня можна було розповісти окремо. I ось ти починаєш розповідати. А що можна розповісти про те, чого ти насправді не бачив... I у Ворошиловграді жодного разу не був. Та й немає тепер ніякого Ворошиловграда (S. Zhadan. Voroshylovhrad) (Voroshylov could be either on horseback or without a horse. But then again, it is worse since you could tell a separate story about the horse. And so you start telling. But what can you tell about something you've never really seen... Neither have you been to Voroshylovhrad a single time. And after all, there is no Voroshylovhrad now) (S. Zhadan. 
Voroshylovhrad). The monument to Voroshylov is fiction; the city is fiction; and the old regime itself is forgotten history.

In contrast to the practice of word formation in the 1920s, it is less common for modern Ukrainian writers to resort to "self-produced" occasional words; novel word-formations are more characteristic of the poetic style; preference is given to various unusual combinations of words used with appositives, etc. Used for stylistic purposes, newly formed words characterize a phenomenon in a new way. As noted by H. M. Vokalchuk, "individual authorial lexemes are meant to provide an original reflection of the poet's unique vision and perception of the world; they are specific markers of authorial style, 'a product' of complex interrelations in the 'world-language-speaker' triad" [3, p. 14]. Thus I. Kalynets' novel word-formations found in the text

Весник - скоро вість:(Vesnyk - skoro vist:)

i Скорозріст, і Лозовість (i Skorozrist i Lozovist)

suggest that the author uses the inexhaustible potential of word-formation for the sake of creating a unique lyrical style, with a polyphonic play triggered by the elements $8 е c H-$, iicmb, -8icmb, -spicm.

In the context of the general literary tendency towards renewing stylistic manner on the basis of new linguistic devices, the abandonment of the old-fashioned populist tradition, there is growing interest in idiostyles, which have distinct features of a new language style marked by, on the one hand, a return to ancient written records and, on the other hand, a study of unusual writing which illuminates the author's "linguistic personality". To illustrate, V. Shevchuk's discursive system is characterized by using real and imaginary, phantasmagoric, images; reflecting the abyssal, archetypal, transcendental in human consciousness [9, p. 288]. Through the mythologem Oko Prirvy (The Eye of the Abyss), the author creates, for instance, a symbolic image of superpower which accompanies a person in their search for faith and truth: Воно дивиться, те Око Прірви, із жіночих та чоловічих очей, $і я$ починаю боятися їхньої урекливості; воно як шиба у вікні, поранена західним чи східним промінням; воно - звір чи тварина, яких несподівано дякаєшся, коли постають перед тобою; пес, щзо криваво зорить на тебе, ошкірюючи зуби; кабан, бик, півень чи гусак - тобто воно в усьому і всюдисуще (V. Shevchuk. Oko Prirvy) (It stares at me, that Eye of the Abyss, through female and male eyes, and their jinxing ability begins to frighten me; it is like a windowpane injured by eastern or western sunlight; it is a beast or an animal that scares you when it appears suddenly in front of you; a dog glaring at you with blood-thirsty eyes, gnashing its teeth; a hog, a bull, a rooster, or a goose - in other words, it inhabits everything and is omnipresent) (V.Shevchuk. The Eye of the Abyss). The text is an example of a complicated, extended narrative style with frequent enumerations and bookish phrases such as боятися їхньої урекливості (their jinxing ability frightens mе), поранена промінням (injured by sunlight), зорить на тебе (glaring at you), в усьому і всюдисуще (it inhabits everything and is omnipresent); the combination of the two concepts - sacrum (the sacred) and profanum (the profane) [14] - serves as a foundation for the writer's languagemediated thought.

Another prominent feature of modern novostyl is an unlimited combination of lexical elements, including the ones tabooed in the classical paradigm, in one linguistic space. Clashing such components in the author's or the character's speech is becoming a norm - they lose their shock value and enter the lexicon of the narrative as natural elements, at least in the author's perception. A typical example of such word use is a mixture of bookish words and profane language, which is an organic feature of modern discourses. Such "destructive" word use is common for postmodernist writers who reflect this linguistic practice, not without considering the fact that such language marks a "cultured" person who allows themselves linguistic "freedoms". To illustrate, I. Karpa's idiostyle is marked by an unlimited variety of combinations of numerous words used by the intelligentsia with rude vulgarisms; cf.: вічний коїтус (eternal coitus), інтелектуальні амбіиї̈ (intellectual ambitions), великомасштабна параноя (а largescale paranоіа), різноманітні гіпі і реліктові металісти усіх конфігурацій (various hippies and relict metalheads of all configurations), мікроскопічна вселенська гармонія (microscopic universal harmony), суціильна redemption song (a solid redemption song), жодному хаккінену і не снилося (beyond a häkkinen's dreams); cf. the parallel use of the words: Дівчисько аж пісялося від щзастя (I. Karpa. 50 khoylyn travy) (The chit of a girl was just pissing herself with joy) (I. Karpa. 50 Minutes of Grass) and so on. 
The recent literary practice of using obscene language, which is mainly characteristic of the younger generation of writers, suggests a desire to abandon the established norms of a mealy-mouthed writing manner devoid of colloquial reality; to individualize style by keeping it free from rules and norms of the past; to establish a writing manner focused on a new "norm" free from restrictions imposed by traditional word use. As noted by L. Stavytska, "the prescriptive approach to linguistic phenomena can be viewed in the context of Ukrainian linguistic studies ignoring the anthropocentric paradigm, ignoring the linguistic personality per se, a person as a language speaker, and hence dehumanizing the notion of language itself" [12, p. 25]. The authors who freely use offensive language offer rather shallow explanations: ... одна поважна жінка звинуватила мене в надмірному вживанні ненормативної лексики. Але, як сказав герой одного комедійного фільму, коли тобі на ногу падае цеглина, ти навряд чи станеш підиуковувати слово для вигуку (I. Rozdobudko. Odnoho razu...) (... a respectable woman accused me of using non-standard language excessively. But, as a comedy movie character said, when a brick falls down on your foot, you are unlikely to start selecting a word for an interjection) (I. Rozdobudko. Once upon a time...). Having a sense of moderation, avoiding violation of literary norms in the language of the author and their characters is ceasing to be obligatory.

It has become common for writers to include numerous elements of the English language; its use varies in individual authors, but as a tendency it is rather prominent. To illustrate, I. Karpa's texts contain not only individual English phrases but also extended passages. Such elements mark the language of those characters who address each other in "fashionable" English expecting the interlocutor to speak it; less justifiable is the use of English words in the author's speech intended to communicate with a "cultured" reader. Let us consider a text where an English-speaking character and a Ukrainian author echo each other: ... тебе з чемності прочено почитати рідною мовою - уои теаn, it is not Russian? - i ти стала читати, з обиди й розпуки (остопранцуюватіли зі своїм Russian'oм ще тоді!) слухаючи тільки власний текст, ховаючись у нього... (O. Zabuzhko. Poliovi doslidzhennia ukrainiskoho seksu) (... out of politeness you were asked to read in your native language - you mean, it is not Russian? - and you began reading then, out of insult and desperation (you were sick to death of their Russian even back then!) listening only to your own text, concealing yourself within it...) (O. Zabuzhko. Fieldwork in Ukrainian Sex). Worthy of attention is Russian'om composed of the English word Russian and the Ukrainian inflection $-o \mathcal{M}$, which expresses the instrumental case.

Elements of Russian as a stylistic feature are usually introduced with a view to poking fun at a speaker of this language; they are often distorted thus becoming indicative of a macaronic language (referred to as surzhyk in Ukrainian); as regards linguistic material, preference is usually given to everyday words, which indicate the speaker's lack of education; cf.: Боже, які дурні діалоги веде якась маман з дитиною: «Ряську кушают кури, уткі», - «А гріби вабще палєзни?», - «Вся єда палєзна!», «Даже мухамори?!», - «Для животних - да...» Самі ви животні (I. Karpa. 50 khoylyn travy) (God, what silly dialogues a certain mamma has with her child: "Duckweeds are eaten by hens, ducks", - "Are mushrooms good to eat at all?" - "All food is good to eat!" - "Even fly-agarics?!, - "For animals - yes...". It's you who are animals) (I. Karpa. 50 Minutes of Grass).

The texts of the representatives of "a new generation" of writers are marked by the tendency towards limiting ethnographic material in order to abandon old-fashioned "patriarchy", pseudonationalism; the discourse of the older generation does not avoid culture-specific language; cf.: $Я$ no свimy idy в вишиванці (I am treading the world in a vyshyvanka*) (I. Drach). On the other hand, the discourse of "fashionable" authors is armed with local vernaculars; dialectal words enter the narrative organically not so much as a means of reproducing "local color", as linguists used to note, but rather as natural speech of the author and their characters, as a modern system of communication. V.V. Greshchuk writes that "in a literary language there can be so-called 'unopposable' lexical dialecticisms, without which a writer cannot do in descriptions of landscapes, daily routine or other characterizations" [4, c. 291]; limited norms of using local speech do not exclude its presence in authorial style; cf.:

\footnotetext{
* Transl. note: a vyshyvanka is a Ukrainian embroidered shirt, part of the Ukrainian national costume.
} 
Ябка солодкі, та стали ви квасно-винні...

(Little sweet apples, you became sour winy ...)

Не треба, ненько, мені твого віна

(No wine of yours for me, mummy) (T. Melnychuk).

The uninhibited use of words and phrases carrying various stylistic connotations is becoming a prominent feature of "Lviv speech", which is mainly found in the texts of western Ukrainian authors, cf.:

- До речі, шановні, чи вам щзось відомо про пана Мавропуле? Приїхав уже чи ні? (- By the way, dear, do you know anything about Mr. Mavropule? Has he come yet or not?)

- Маю вражіння, що ні, - дала до зрозуміння Ада... ( - I have the impression that he hasn't, Ada let them know...)

Ада з Перфецьким ще довший час наслухали виразне цьокотіння підків за плечима (Yu. Andrukhovych. Perverziia) (Quite long afterwards, Ada with Perfetskyi could hear the distinct clatter of horseshoes behind their shoulders) (Yu. Andrukhovych. Perversion). This text contains words imitating Polish.

The syntactic stylistic devices used by modern authors can often be regarded as deviations from literary norms; they include an intentional violation of word order with a view to "combining the uncombinable"; jumbled utterances connected only by way of association; a sequence of such utterances strung together; a text parsed into separate, semantically unconnected, fragments or, vice versa, a discourse viewed from a spatiotemporal perspective but lumped in one monologue. According to N. V. Kondratenko, such a syntax is "not a total violation of textual structure or content but a special type of this structure (or content) which, similarly to the methods of 'shock therapy', influences the addressee" [ 8, p. 87-88]. Such an innovative stylistic manner is marked by a shift in the lexicalsemantic connections between word components; the text is saturated with numerous interruptions in narration, new messages, and interjections as manifestations of a free writing manner. For instance, in O. Zabuzhko's novel the utterance У кухні - крихітний eat-in kitchen... (In the kitchen - a tiny eat-in kitchen...) consists of over 90 words and includes a long string of enumerations, comment clauses, interjections and exclamations, combinations such as йому-же-несть-кіниял (there-is-no-end-to-it) and so on. Such writing manner is not unique of this author alone - it is representative of many discourses of today.

The syntactic organization of modern writing has distinct features of personal style; let us compare the following fragments of speech broken down into short utterances:

I Він [Творець] стукае того в чоло: отримайте-розпишіться!

(And He [the Creator] is striking that one on his forehead: sign for receipt!)

I дає цзей дар або як велике щзастя, або як важкий тягар.

(And he gives this gift as either great happiness or a heavy burden.)

Або як «два в одному»: $і$ те, й інше - водночас.

(Or as "two in one": both one and the other - at a time.)

I не відомо, що краще: мати його в собі чи не обтяжуватися зайвим.

(And who knows which is better: to have it inside or not to burden yourself with unnecessary things.)

Я чесно не знано, щз краше...

(I honestly don't know which is better...)

Носити в собі цей дар досить небезпечно (I. Rozdobudko. Odnoho razu...).

(To keep this gift to yourself is rather dangerous) (I. Rozdobudko. Once upon a time...).

As regards the tone of narration, there is a suggestion of doubt, hesitation, warning; there is an atmosphere of uncertainty, complicated decisions; broken speech reflects the emotional character of the narrative. The desire to come closer to the reader manifests itself, for instance, in the introduction of the author who assumes the function of the I-narrator, who tells the story in the first person; the reader's trust in such communication is enhanced; the author's intentions show features of an idiostyle while being influenced by an "invisible" recipient. 


\section{CONCLUSIONS}

The cumulative linguistic and literary product, which reflects fictional reality in new stylistic forms and solutions, largely explicates the features of modern movolstyl - a heterogeneous, multi-faceted phenomenon capturing modern changes in the system of linguistic expressive means, avoiding the stereotypes of the classical paradigm, and searching for novel approaches to building a text. The renewed founding principles of linguistic poetics "preached" by "masters" and "non-masters" of literature show that on the way to national and cultural self-identification the idiolect of modern Ukrainian writers has acquired a new quality. Without discarding the principles of fictional discourse adhered to by literature classics, present authors are modernizing style by searching for linguistic and aesthetic "signs" which can identify the individual writing of every author; while doing so, they sometimes observe or violate the stylistic norms of a particular literary trend, standardized literary rules. Renewed language-mediated thought serves as a foundation for creating authorial style by providing a variety of techniques and non-typical linguistic realizations of artistic intentions. Avenues for further research may involve a comprehensive fundamental study of novostyl in its connections with the classical literary tradition.

\section{REFERENCES}

[1] Білодід І.К. Мова творів Олександра Довженка. Вид-во Акад. наук УРСР, Київ, 1959.

[Bilodid I.K. Mova tvoriv Oleksandra Dovzhenka. Vyd-vo Akad. nauk URSR, Kyiv, 1959.]

[2] Гундорова Т.I. Післячорнобильська бібліотека. Український літературний постмодерн. Критика, Київ, 2005.

[Hundorova T.I. Pisliachornobylska biblioteka. Ukrainskyi literaturnyi postmodern. Krytyka, Kyiv, 2005.]

[3] Вокальчук Г.М. Авторський неологізм в украйнській поезї ХX століття (лексикографічний аспект). Перспектива, Рівне, 2004.

[Vokalchuk H. M. Avtorskyi neolohizm v ukrainskii poezii XX stolittia (leksykohrafichnyi aspekt). Perspektyva, Rivne, 2004.]

[4] Грещук Вас.В., Грещук Вал.В. Південно-західні діалекти в украйнській художній мові. Вид-во Прикарпатського національного університету ім. В. Стефаника, Івано-Франківськ, 2010.

[Greshchuk Vas.V., Greshchuk Val.V. Pivdenno-zakhidni dialekty v ukrainskii khudozhnii movi. Vyd-vo Prykarpatskoho natsionalnoho universytetu im. V. Stefanyka, Ivano-Frankivsk, 2010.]

[5] Ермоленко С.Я. Мовно-естетичні знаки української культури. Ін-т української мови НАН України, Київ, 2009.

[Yermolenko S.Ya. Movno-estetychni znaky ukrainskoi kultury. In-t ukrainskoi movy NAN Ukrainy, Kyiv, 2009.]

[6] Ермоленко С.Я. Нариси з української словесності (стилістика та культура мови). Довіра, Київ, 1999. [Yermolenko S.Ya. Narysy z ukrainskoi slovesnosti (stylistyka ta kultura movy). Dovira, Kyiv, 1999.]

[7] Карасик В.И. Языковая матрица культуры. Гнозис, Москва, 2013.

[Karasik V.I. Yazykovaia matritsa kultury. Gnozis, Moskva, 2013.]

[8] Кондратенко Н.В. Синтаксис українського модерністського $і$ постмодерністського художнього дискурсу. Видавничий дім Дмитра Бураго, Київ, 2012.

[Kondratenko N.V. Syntaksys ukrainskoho modernistskoho i postmodernistskoho khudozhnoho dyskursu. Vydavnychyi dim Dmytra Buraho, Kyiv, 2012.]

[9] Кононенко В. Аінгвопоетичні етюди. ДВНЗ “Прикарпатський національний університет імені Василя Стеф.”, Київ; Івано-Франківськ, 2018.

[Kononenko V. Linhvopoetychni etiudy. DVNZ "Prykarpatskyi natsionalnyi universytet imeni Vasylia Stef.", Kyiv; Ivano-Frankivsk, 2018.]

[10] Кононенко B.I. Український верлібр: інтерпретація текстів. Вісник Прикарпатського університету. Філологія, 46 (2019), 95-103.

[Kononenko V.I. Ukrainskyi verlibr: interpretatsiia tekstiv. Visnyk Prykarpatskoho universytetu. Filolohiia, 46 (2019), 95-103.] 
[11] Кульбабська О., Шаталова Н. “Пишу як серце диктує..." (Ідіостиль Сидора Воробкевича). Чернівецький нац.ун-т, Чернівці, 2016.

[Kulbabska O., Shatalova N. "Pyshu yak sertse dyktuie..." (Idiostyl Sydora Vorobkerycha). Chernivetskyi nats. un-t, Chernivtsi, 2016.]

[12] Сологуб Н.М. Мовний світ Олеся Гончара. Наукова думка, Київ, 1991.

[Solohub N.M. Movnyi svit Olesia Honchara. Naukova dumka, Kyiv, 1991.]

[13] Ставицька А. Арго, жаргон, сленг. Критика, Київ, 2005.

[Stavytska L. Arho, zharhon, slenh. Krytyka, Kyiv, 2005.]

[14] Zambrzycka M. Sacrum i profanum w prozie Wałerija Szewczuka. KU “W kręgu języka, literatury i kultury", Warszawa-Iwano-Frankiwsk, 2015.

Address: Vitaliy Kononenko, Vasyl Stefanyk Precarpathian National University, 57 Shevchenko St., IvanoFrankivsk, 76025 Ukraine.

E-mail: kzm.pu.if@ukr.net

Received: April 7, 2020; revised: November 17, 2020.

Кононенко Віталій. Ідіостилістичні параметри художнього дискурсу. Журнал Прикарпатського університету імені Василя Стефаника, 7 (2) (2020), 51-60.

У статті розглянуто проблему визначення параметрів індивідуально-авторського стилю сучасних українських письменників. Окреслено завдання відображення в ідіостилі автора психодінгвістичних чинників народної самосвідомості, відтворення в системі самовираження національного психотипу, українського ментального світорозуміння. Накреслено шляхи подальшого опрацювання асоціативно-оцінної діяльності наратора з виявом їі самодостатності й неповторності, яка через образне бачення створює мовну картину художньої дійсності. Осмислення художньої творчості розглянуто як посилення впливу на свідомість адресата: утвердження пріоритетів національного мовомислення, впровадження нових літературних норм. Поняття «індивідуальний стиль письменника» постає як компдексний стильотвірний конструкт у багатовекторному мовностилістичному вираженні.

Звернуто увагу на теорію мовостилю, орієнтовану передовсім на опрацювання оновлених мовно-естетичних засобів, тенденцій функціонування художнього дискурсу, що характеризується різностильовою практикою, відмовою від стереотипної манери письма, змінами в формуванні своєрідної образності. Аналіз сучасного художнього ідіолекту загалом і стильових рис текстів провідних авторів дає змогу окреслити закономірності зрушень у системі метафоризації, визначити процеси модернізації стильових ознак, мовностилістичні закономірності розвитку новостилю. Поточнено тлумаченя дефініцій на позначення авторського стилю художнього мовлення. У ході дослідження стильової індивідуалізації текстів використаний дискурс-аналіз художньої мовотворчості сучасних українських письменників різних напрямів і спрямувань, який забезпечує вивчення взаємодії на рівні автор-текст-читач.

Сучасний мовно-літературний продукт, що відтворюе реалії дійсності в нових стильових формах і рішеннях, експлікуе особливості сучасного мовостилю як явища неоднорідного, багатовекторного, що фіксує зміни в структурі мовно-виражальних засобів. В умовах національнокультурної самоідентифікації ідіолект українського письменства здобуває нову стильову модель. Сучасні автори модернізують засоби образотворення, знаходять мовно-стилістичні знаки культури, що роблять кожного автора носієм індивідуального письма.

Ключові слова: ідіолект, ідіостиль, індивідуально-авторський стиль, метафора, мовостиль, образ, новостиль, текст, художній дискурс. 